\title{
Makna Cantik di Kalangan Mahasiswa Fakultas Ilmu Sosial Universitas Negeri Padang
} Angkatan 2015

\author{
Sri Wahyuni, Erianjoni Erianjoni ${ }^{2}$, Mira Hasti Hasmira ${ }^{3}$ \\ 1,2,3Universitas Negeri Padang \\ email: sw2019948@gmail.com
}

\begin{abstract}
Abstrak
Artikel ini membahas tentang makna cantik dikalangan mahasiswa Fakultas Ilmu Sosial UNP Angkatan 2015. Penelitian ini dilatarbelakangi karena keingintahuan penulis akan bagaimana makna cantik bagi mahasiswa. Karena diketahui dari hasil pengamatan penulis ditemukan adanya perbedaan persepsi dalam hal memaknai cantik yang cenderung dilihat dari penampilan sehingga mahasiswa berusaha tampil cantik dengan memakai riasan ke kampus sehingga cantik menjadi sebuah kebutuhan akan pengakuan sosial, penghargaan dan aktualisasi diri. Oleh karena itu, penelitian ini dianalisis dengan menggunakan teori Fenomenologi oleh Alfred Schutz. Penelitian ini menggunakan pendekatan penelitian kualitatif dengan tipe penelitian studi fenomenologi. Hasil penelitian menunjukkan bahwa Hasil penelitian menunjukan bahwa terdapat berbagai persepsi cantik bagi setiap mahasiswa dalam berpenampilan ke kampus. Mahasiswa memaknai cantik lebih kepada makna objektif yang dilihat dari segi: (1) berkulit putih, (2) berpenampilan menarik, (3) wajah (4) sikap dan perilaku daripada makna subjektif yang dilihat dari segi hati, jiwa dan berpikiran positif. Para mahasiwa yang ingin terlihat cantik menganggap jika mereka merias diri dan mengikuti trend maka mereka akan diterima dalam lingkungan sosial.
\end{abstract}

Kata Kunci: Makna Cantik, Mahasiswa

\begin{abstract}
This abstract discusses the meaning of beauty among the students of the faculty of Social Sciences UNP Class 2015. This research is motivated by the author's curiosity about how beautiful is meant for students. Because it is known from the observations of the authors found that there are differences in perceptions in terms of interpreting the beautiful tend to be seen from the appearance so that students try to look beautiful by wearing makeup to campus so that beautiful becomes a need for social recognition, appreciation and self-actualization. Therefore, this study was analyzed using Phenomenology theory by Alfred Schutz. This study uses a qualitative research approach with a type of phenomenological study research. The results showed that the results showed that there were various beautiful perceptions for each student in performing on campus. Students interpret the beauty more to the objective meaning seen in terms of: (1) white, (2) attractive appearance, (3) face (4) attitude and behavior rather than subjective meaning which is seen in terms of heart, soul and positive thinking. Students who want to look beautiful assume that if they make up and follow the trend, they will be accepted in a social environment.
\end{abstract}

Keywords: Beautiful Meanings, Students 


\section{Pendahuluan}

Penampilan menjadi suatu perhatian utama bagi seluruh kalangan terlebih pada kaum wanita. Setiap wanita selalu berkeinginan untuk memiliki penampilan yang sempurna karena kecantikan merupakan salah satu hal yang paling penting, bukan hanya dalam berpakaian, namun juga kecantikan pada kulit wajah dan tubuh sudah menjadi prioritas utama dalam berpenampilan. ${ }^{1}$ Makna kecantikan yang hadir pada saat ini merupakan konstruksi sosial yang tidak lagi memaknai cantik sebagaimana cantik, tetapi cantik hari ini menjadi sebuah kebutuhan akan pengakuan sosial, penghargaan dan aktualisasi diri. Pemahaman sebagian masyarakat yang menganggap bahwa cantik itu putih sangat dipengaruhi oleh kekuatan media dalam mengkonstruksi kecantikan. Selain itu juga terdapat konteks kecantikan yang mendunia bahwa cantik itu berkulit putih, tinggi dan berambut lurus. ${ }^{2}$ Konsep cantik dapat mempengaruhi perilaku masyarakat, misalnya cara seseorang menghargai dirinya dan memandang orang lain. ${ }^{3}$

Pemahaman tersebut mempengaruhi mahasiswa yang sedang menuntut ilmu pengetahuan di perguruan tinggi. Keinginan mahasiswi untuk mempercantik diri seringkali mendominasi mereka yang terlalu mengagungkan sisi kecantikan sehingga menyebabkan mahasiswi menjadi sangat terobsesi pada penampilan yang cantik dan melupakan bahwa kecantikan itu sendiri meliputi kecantikan dari dalam yang dinamakan inner beauty dan kecantikan yang berasal dari luar. Kecantikan dari dalam dapat terpancar dari kondisi fisik yang sehat dan budi pekerti yang baik. Sedangkan kecantikan dari luar dapat ditunjang penampilan fisik dan tata rias yang tepat yaitu kosmetik. ${ }^{4}$ Individu dapat berpartisipasi (ikut serta) dengan lingkungannya, dan individu senantiasa berusaha untuk menyesuaikan dirinya dengan lingkungannya. ${ }^{5}$ Sama halnya dengan mahasiswi akan dianggap mengikuti perkembangan zaman dan mendapat "label" yang mengangkat harga dirinya apabila telah mengikuti trend seperti memakai bedak yang tebal, blush on di bawah mata, eyeliner, mascara, alis serta lipstick sewaktu pergi ke kampus.

Pada topik ini, peneliti lebih menfokuskan kepada mahasiswa yang memakai riasan ke kampus. Seorang mahasiswa pada dasarnya mempunyai kewajiban untuk menuntut ilmu sebanyak mungkin, mencapai kemandirian emosional, mengembangkan konsep, meningkatkan keterampilan intelektual, mampu membangun tanggung jawab sosial, serta mampu membina hubungan baik dengan anggota kelompok yang lain. Mahasiswa tersebut dipengaruhi motif emosional seperti hal-hal yang bersifat pribadi atau subyektif seperti status, harga diri, perasaan cinta dan lain sebagainya. Mahasiswa yang dipengaruhi oleh motif emosional tidak mempertimbangkan apakah barang yang dibelinya sesuai dengan dirinya, sesuai dengan kebutuhannya, sesuai dengan kemampuannya, dan sesuai dengan standar atau kualitas yang diharapkannya. ${ }^{6}$ Hal itu menunjukkan kecenderungan mahasiswa dalam memaknai cantik dalam segi Objektif atau dari luar yang sebagaimana mestinya kecantikan dari segi subjektif atau dari dalam juga sangat penting.

\footnotetext{
${ }^{1}$ Nurul Fitria Gandhi, Pengaruh Faktor Pribadi dan Sosial Terhadap Keputusan Pembelian Produk Wardah, (Skripsi: UNAND, 2016) Hal. 1

${ }^{2}$ Novitalista Syata, Makna Cantik di Kalangan Mahasiswa Dalam Perspektif Sosiologi,( Skripsi: Universitas Hasanuddin Makasar, 2012) Hal 6-10

${ }^{3}$ Retno Sari, Konstruksi Makna Cantik Bagi Mahasiswi Universitas Riau Berkulit Cokelat, (Skripsi: Universitas Riau,2017) Hal. 2

${ }^{4}$ Rahmiati,dkk, 2013, Merias Diri, Padang: UNP Press, Hal. 142

${ }^{5}$ Abu, Ahmadi. 2009. Psikologi Sosial. Jakarta: Rineka Cipta. Hal 71.

6 Siti Maisyaroh, Hubungan Harga Diri dan Gaya Hidup Hedonis Terhadap Kecendrungan Pembelian Kompuslif Pada Mahasiswa Fakultas Ekonomi UIN Maliki Malang ( Skripsi:. UIN Maliki Malang, 2016. hal. 4 dan 6
} 
Permasalahan diatas, dianalisis dengan menggunakan Teori Fenomenologi oleh Alfred Schutz. Schutz menyatakan bahwa makna berkaitan dengan bagaimana aktor menentukan apa yang penting dari kehidupan sosialnya. Makna muncul ketika dihubungkan dengan pengalaman-pengalaman sebelumnya serta melalui proses interaksi dengan orang lain. Karena itu, tindakan manusia selalu mempunyai makna. Makna terdiri dari makna Subjektif dan makna objektif. Artinya, makna cantik kini telah terkonstruksi dari masyarakat lingkungan sekitar sehingga makna cantik dominan dilihat dari segi objektif.

\section{Metode Penelitian}

Penelitian dilakukan di selingkungan kampus UNP. Penelitian ini menggunakan pendekatan kualitatif dengan tipe penelitian studi fenomenologi. Pemilihan informan penelitian dilakukan secara purposive sampling dengan cara pengambilan sampel secara sengaja. Maksudnya, peneliti menentukan sendiri sampel yang diambil dengan cara menetapkan ciri-ciri khusus yang sesuai. Purposive sampling dilakukan dengan mengambil orang-orang yang terpilih betul oleh peneliti menurut ciri-ciri spesifik yang dimiliki oleh sampel itu dengan jumlah informan sebanyak 25 orang. Data penelitian dikumpulkan melalui teknik observasi, wawancara dan studi dokumen. ${ }^{7}$ Agar data yang diperoleh bisa dipercaya (absah), maka dalam penelitian ini dilakukan proses triangulasi data. Triangulasi data dilakukan dengan cara memberikan pertanyaan yang sama kepada informan yang berbeda. Jawab-an yang relatif sama pada masing-masing informan dianggap valid apabila sesuai dengan pengamatan dan studi dokumen yang peneliti peroleh maupun dengan menggunakan teknik lainnya.

Kemudian data yang diperoleh dianalisis dengan menggunakan teknik analisis data yang dikemukakan oleh Milles dan Huberman dengan langkah reduksi data, display data, dan tahap menarik kesimpulan/verifikasi. ${ }^{8}$ Dimana aktivitas dalam analisis data ini, dilaku-kan secara terus menerus pada setiap tahap penelitian sampai tahap penelitian ini selesai.

\section{Makna Cantik Dikalangan Mahasiswa Fakultas Ilmu Sosial Universitas Negeri Padang Angkatan 2015}

Cantik dan wanita bagaikan dua sisi mata uang yang tidak dapat dipisahkan. Sangatlah wajar apabila seorang wanita ingin selalu tampil cantik. Meskipun secara naluriah kodrat setiap wanita adalah cantik, kebanyakan wanita terobsesi memperjuangkan kecantikan dengan berbagai cara seperti halnya para mahasiswa yang juga ingin tampil cantik salah satu caranya dengan menggunakan kosmetik.

Hasil temuan menunjukkan bahwa terdapat berbagai persepsi cantik bagi setiap mahasiswa dalam berpenampilan ke kampus. Mahasiswa memaknai cantik lebih kepada makna objektif daripada makna subjektif. Makna cantik dikategorikan dalam Makna Objektif dan Makna Subjektif, seperti penjelasan di bawah ini:

\section{Makna Objektif}

\section{Berkulit putih}

Keinginan yang tinggi untuk menjadi cantik dapat mempengaruhi prilaku dan tindakan para mahasiswi yang berupaya untuk menjadikan kulit mereka putih dengan menggunakan produk-produk pemutih seperti yang lainnya sehingga akan timbul rasa percaya diri dan nyaman saat berinteraksi dengan lingkungan sosial, terutama di lingkungan kampus.

\footnotetext{
${ }^{7}$ Basrowi \& Suwandi. 2008. Memahami Penelitian Kualitatif. Jakarta: Rineka Cipta. Hlm. 94

${ }^{8}$ Afrizal. 2016. Metode Penelitian Kualitatif. Sebuah Upaya Mendukung Menggunakan Penelitian Kualitatif dalam Berbagai Disiplin

Ilmu. Jakarta: PT. Raja Grafindo Persada. Hlm. 180
} 
Jika dikaitkan dengan teori yang dikemukakan oleh Alfred Schutz, beliau mengatakan bahwa fenomenologi memfokuskan studinya pada masyarakat berbasis makna yang dilekatkan oleh anggota. Hal itu menjadi stock of knowledge yang memungkinkan dia memahami makna dari apa yang dikatakan atau dilakukan orang lain seperti adanya realitas yang dialami oleh orang-orang berupa pengetahuan atau pemahaman sehingga membentuk dan mengarahkan mereka dalam berhubungan dengan orang lain di sekitarnya. Hal itu terbukti dari penuturan informan-informan yang memiliki jawaban yang sama yang mengungkapkan bahwa cantik itu tidak dinilai oleh individu namun masyarakat atau orang yang berada di sekelilingnya, adanya pemahaman dalam masyarakat itu sendiri bahwa cantik adalah perempuan yang memiliki kulit putihlah yang menjadi patokan bagi individu tersebut.

2. Berpenampilan menarik,

Penampilan sangatlah mendukung untuk seseorang terlihat cantik dari segi pakaian yang digunakan, aksesoris pendukung yang modis dan fashionable serta hal-hal lain yang akan menunjang penampilan agar menarik. Menurut mereka penampilan juga menjadi tolak ukur seseorang dikatakan cantik atau tidak. Segala sesuatu yang digunakan akan menjadi point tersendiri untuk mereka agar menambah sisi kecantikan terhadap dirinya. Tanggapan dari orang lain juga sangat mempengaruhi individu tersebut.

Jika dikaitkan dengan teori, Schutz mengatakan Fenomenologi menfokuskan studinya pada masyarakat berbasis makna yng dilekatkan oleh anggota. Hal itu menjadi stock of knowledge yang memungkinkan dia memahami makna dari apa yang dikatakan atau dilakukan orang lain. Pada penelitian ini, terlihat adanya sikap mahasiswa yang juga berpatokan terhadap tanggapan dari orang lain selaku temannya terkait yang ia pakai ke kampus.

3. Wajah

Wajah menjadi dasar seorang perempuan agar dapat dinilai cantik ataupun tidak cantik oleh orang lain. Ketika seorang perempuan merasa memiliki kekurangan pada wajah mereka, maka mereka memoles wajah mereka dengan make up. Make up menjadikan perempuan tampil lebih cantik dan menarik di masyarakat, mereka juga merasa lebih percaya diri dengan make up.

Jika dikaitkan dengan teori Alfred Schutz, beliau mengatakan bahwa keberadaan stok pengetahuan ini memberikan ciri take for granted (menerima sesuatu begitu saja tanpa mempertanyakannya). Dalam penelitian ini, mahasiswa memakai apa saja yang sedang trend pada saat itu tanpa mengetahui lebih jelas, yang terpenting bagi mereka adalah mengikuti zaman dan kekinian. Contohnya ketika trend memakai blush on yang biasanya dipakai di pipi sekarang berubah di bawah mata dengan menggunakan lipstik, para mahasiswa mengikutinya begitu saja dan yang terpenting bagi mereka kekinian dan dapat dianggap cantik.

4. Sikap dan perilaku

Cantik tidak hanya dinilai dari seberapa cantik wajah dan menariknya penampilan, namun juga dinilai dari caranya bersikap dan berprilaku saat sedang berinteraksi dengan orang di sekitarnya berada. Menurut mereka, mahasiswa yang berpenampilan sederhana tanpa menggunakan riasan umumnya memiliki tutur kata yang baik dan lemah lembut, ini terlihat dari cara mereka berinteraksi.

\section{Makna Subjektif}

1. Jiwa dan hati

Dalam kehidupan sehari-hari, baik mulai dari diri sendiri, masyarakat, dan bersosialisasi dengan siapaun pasti tidak akan terlepas dari akhlak, kecantikan seorang perempuan dapat dilihat dari akhlaknya. Menurut mereka, cantik tidak hanya di lihat dari segi luar (outer beauty) namun juga dilihat dari segi dalam (inner beauty). 
Jika dikaitkan dengan teori Fenomenologi oleh Alfred Schutz, individu memiliki dan menerapkan pengetahuan yang terdiri dari semua fakta, kepercayaan, dan aturan yang dipelajari dari pengalaman pribadi dan pengetahuan yang telah tersedia. Seperti para mahasiswa yang memahami cantik juga dilihat dari jiwa dan hati, mereka percaya bahwa hal tersebut akan memancarkan aura tersendiri yang akan memperlihatkan kecantikan mereka yang terpancar dari segi outer beauty.

2. Berpositif thingking

Selalu berpikiran positif juga akan mempengaruhi seseorang dalam menampilkan dirinya di lingkungan sosial. Individu yang sering mensugestikan dirinya menarik, maka akan menimbulkan kepercayaan diri dan menerima diri apa adanya. Menurut mereka, cantik tidak selalu berkenaan dengan tampilan luar saja, namun cantik dari dalam juga sangat diperlukan seperti selalu berpositif thingking, berpikiran yang baik agar diri tersugesti dengan hal-hal yang baik pula sehingga memunculkan aura kecantikan tanpa harus memakai riasan yang tebal ke kampus.

Jika dikaitkan dengan teori Fenomenologi oleh Alfred Schutz, individu memiliki prasangka tersendiri terhadap apa yang dipahami. Sama halnya dengan mahasiswa yang berpikiran positif terhadap apa yang ia lakukan. Sehingga berdampak dengan dirinya sendiri seperti mensugestikan dirinya bahwa ia menarik dan cantik.

Berbicara mengenai perempuan, adalah berbicara mengenai kecantikannya, karenanya tuntutan untuk selalu tampil cantik akan selalu mengikuti sosok perempuan kemana pun ia pergi, dimana pun ia berada dan pada usia yang mana pun. Sebagai sebuah komoditas, kecantikan adalah ladang yang tidak habis-habisnya digali. Banyak pihak yang mengerti bahwa ada keuntungan yang luar biasa didapat dengan terus menggali kecantikannya seperti yang dijelaskan di bawah ini:

1. Menarik perhatian laki-laki

Selain menarik perhatian laki-laki, peneliti menemukan fakta di lapangan bahwa wanita yang cantik lebih dihargai di lingkungan terutama pada kaum laki-laki. Menurut mereka, wanita yang dapat menarik perhatian laki-laki akan merasa lebih di hargai lingkungan sosial daripada wanita yang tidak cantik, tidak dipungkiri dihargai oleh lingkungan dan masyarakat adalah salah satu kebahagiaan yang diharapkan para wanita karena ia merasa lebih di akui keberadaannya.

2. Lebih percaya diri

Banyak wanita yang tidak percaya diri terhadap dirinya sehingga mengakibatkan wanita berprilaku sosial cendrung pasif, dia akan merasa serba kurang dan tidak puas dalam memandng dirinya.

3. Mendapat pujian

Dari hasil temuan di lapangan saat wawancara secara mendalam, peneliti menemukan fakta bahwa selain mendapatkan pujian, mahasiswa tersebut juga mendapatkan perhatian.

Keinginan untuk terlihat cantik mendorong para mahasiswa melakukan berbagai upaya agar mendapatkan label cantik. Sebagian dari mahasiswa memiliki perekonomian yang tergolong menengah, namun mereka tetap berusaha untuk memenuhi kebutuhan kosmetik tersebut. Upaya-upaya yang mereka lakukan untuk memenuhi kebutuhan kosmetik diantaranya:

1. Menghemat uang bulanan

Dalam memenuhi kebutuhan kosmetik, ada beberapa mahasiswa yang berupaya menghemat uang bulanannya agar bisa membeli produk-produk kosmetik, dengan berhemat maka para mahasiswi bisa menabung uangnya yang digunakan untuk membeli berbagai produk kosmetik. 
2. Mendapatkan uang tambahan dari pacar

Salah satu cara lainnya yaitu dengan mendapatkan uang tambahan dari pacar, seiring berjalannya waktu, fungsi pacar kini telah mengalami pergerakan dimana pacar juga berfungsi sebagai sarana tambahan untuk meminta bantuan dari segi materi.

3. Berbohong

Banyak cara yang dilakukan oleh mahasiswa dalam memenuhi kebutuhan kosmetiknya, salah satu diantaranya yaitu berbohong kepada orangtuanya

4. Jualan Online

Semakin kompleknya kebutuhan para mahasiswa yang tidak di iringi dengan kemampuan secara materi, membuat mereka berusaha mencari uang sendiri baik itu berupa bekerja part time maupun jualan online. Berjualan secara online selain mudah, tidak terikat oleh waktu dan tempat sehingga profesi ini cukup diminati oleh beberapa mahasiswa khususnya bagi perempuan. Dalam kegiatan bisnis online, perempuan menjadi subjek utama, baik dari sisipembeli maupun penjual. Hal ini di sebabkan karena pada dasarnya sifat perempuan cenderung konsumtif dalam membeli barang.

\section{Kesimpulan}

Penampilan menjadi suatu perhatian utama bagi seluruh kalangan terlebih pada kaum wanita. Setiap wanita selalu berkeinginan untuk memiliki penampilan yang sempurna karena kecantikan merupakan salah satu hal yang paling penting, bukan hanya dalam berpakaian, namun juga kecantikan pada kulit wajah dan tubuh sudah menjadi prioritas utama dalam berpenampilan. Makna kecantikan yang hadir pada saat ini merupakan konstruksi sosial yang tidak lagi memaknai cantik sebagaimana cantik, tetapi cantik hari ini menjadi sebuah kebutuhan akan pengakuan sosial, penghargaan dan aktualisasi diri. Pemahaman sebagian masyarakat yang menganggap bahwa cantik itu putih sangat dipengaruhi oleh kekuatan media dalam mengkonstruksi kecantikan. Selain itu juga terdapat konteks kecantikan yang mendunia bahwa cantik itu berkulit putih, tinggi dan berambut lurus. Konsep cantik dapat mempengaruhi perilaku masyarakat, misalnya cara seseorang menghargai dirinya dan memandang orang lain.

Berdasarkan hasil penelitian yang telah dilakukan, maka dapat disimpulkan bahwa terdapat berbagai persepsi cantik bagi setiap mahasiswa dalam berpenampilan ke kampus. Mahasiswa memaknai cantik lebih kepada makna objektif yang dilihat dari segi: (1) berkulit putih, (2) berpenampilan menarik, (3) wajah. Sedangkan mahasiswa yang memaknai cantik secara subjektif dilihat dari segi jiwa, hati, dan berpikiran positif cenderung lebih sedikit. Para mahasiwa yang ingin terlihat cantik menganggap jika mereka merias diri dan mengikuti trend maka mereka akan diterima dalam lingkungan sosial.

\section{Daftar Pustaka}

Ahmadi, Abu. (2009). Psikologi Sosial. Jakarta: Rineka Cipta.

Emzir. (2012). Metodologi Penelitian Kualitatif Analisis Data. Jakarta: Rajawali Pers.

Fathori, Abdurrahmat. (2006). Metodologi Penelitian \& Teknik Penyusunan Skripsi. Jakarta: Rineka Cipta.

Fitrawati, Reni. (2009). Kebiasaan Mahasiswi Memakai Produk Pemutih Wajah( Studi kasus: Mahasiswa FIS UNP). Padang: Skripsi UNP.

Gandhi, Nurul Fitria. (2017). Pengaruh Faktor Pribadi dan Sosial Terhadap Keputusan Pembelian Produk Wardah, (Skripsi: UNAND, 2016).http://scholar.unand.ac.id diakses pada tanggal 7 Desember 2017 
Haryanto, Sindung.(2014). Spektrum Teori Sosial: Dari Klasik Hingga Postmodern. Jogjakarta: Ar-Ruzz Media.

Lexy J. Maleong. (2005). Metodologi Penelitian Kualitatif. Bandung: PT Remaja Rosdakarya.

Maisyaroh, Siti. Hubungan Harga Diri dan Gaya Hidup Hedonis Terhadap Kecendrungan Pembelian Kompuslif Pada Mahasiswa Fakultas Ekonomi UIN Maliki Malang ( Skripsi:. UIN Maliki Malang, 2016).

Http://etheses.uin-malang.ac.id diakses pada tanggal 7 Desember

Nazir, Moh . (2005). Metode Penelitian. Bogor: Ghalia.

Oktaviani, Amelia.(2016)Makna Cantik Iklan Wardah Exclusive Versi Dewi Sandra IN Paris. (Sripsi: Universitas Sultan Ageng Tirtayasa, 2016) https://repository.fisipuntirta.ac.id di akses pada tanggal 14 Februari 2018.

Rahmiati,dkk. (2013). Merias Diri. Padang: UNP Press.

Rostamailis. (2009). Seni Mempercantik Diri. Padang: UNP Press.

Rulam, Ahmad. (2014). Metodologi Penelitian Kualitatif. Yogyakarta: Ar-Ruzz Media.

Sari, Retno. Konstruksi Makna Cantik bagi Mahasiswi Universitas Riau Berkulit Cokelat. (Skripsi: Universitas Riau, 2017).

https://media.neliti.com/media/publications/124959-ID-none.pdf diakses pada tanggal 10 Februaru 2018.

Sitorus, MT.Felix. (1998).Penelitian Kualitatif Suatu Perkenalan. Bogor:IPB.

Spradley P. James. (1997). Metode Etnografi.Tiara Wacana Yogya. Yogyakarta.

Sugiyono. (2011). Metode Penelitian Kuantitatif dan Kualitatif dan $R$ \& D. Bandung: Alfabeta.

Sukardi. (2009). Metode Penelitian Pendidikan. Jakarta: Bumi Aksara.

Syata, Novitalista. Makna Cantik di Kalangan Mahasiswa Dalam Perspektif Sosiologi. (Skripsi: Universitas Hasanuddin Makasar, 2012).https://repository.unhas.ac.id diakses pada tanggal 10 Februaru 2018. 